\title{
Expression of $p q q$ Genes from Serratia marcescens W1 in Escherichia coli Inhibits the Growth of Phytopathogenic Fungi
}

\author{
Yong-Hwan Kim', Chul-Hong Kim², Song Hee Han², Beom Ryong Kang ${ }^{2}$, Song Mi Cho ${ }^{2}$, Myung Chul Lee \\ and Young Cheol $\mathrm{Kim}^{2 *}$ \\ ${ }^{\prime}$ National Institute of Agricultural Biotechnology, RDA, Suwon 441-707, Korea \\ ${ }^{2}$ Environmental-Friendly Agriculture Research Center, Chonnam National University, Gwangju 500-757, Korea \\ (Received on August 30, 2006; Accepted on October 17, 2006)
}

Serratia marcescens W1, isolated from cucumbercultivated soil in Suwon, Korea, evidenced profound antifungal activity and produced the extracellular hydrolytic enzymes, chitinase and protease. In order to isolate the antifungal genes from $S$. marcescens $\mathrm{W} 1$, a cosmid genomic library was constructed and expressed in Escherichia coli. Transformants exhibiting chitinase and protease expression were selected, as well as those transformants evidencing antifungal effects against the rice blast fungus, Magnaporthe grisea, and the cucumber leaf spot fungus, Cercospora citrullina. Cosmid clones expressing chitinase or protease exerted no inhibitory effects against the growth of fungal pathogens. However, two cosmid clones evidencing profound antifungal activities were selected for further characterization. An $8.2 \mathrm{~kb}$ HindIII fragment from these clones conditioned the expression of antagonistic activity, and harbored seven predicted complete open reading frames (ORFs) and two incomplete ORFs. The deduced amino acid sequences indicated that six ORFs were highly homologous with genes from $S$. marcescens generating pyrroloquinoline quinone (PQQ). Only subclones harboring the full set of $p q q$ genes were shown to solubilize insoluble phosphate and inhibit fungal pathogen growth. The results of this study indicate that the functional expression of the pqq genes of $S$. marcescens $W 1$ in $E$. coli may be involved in antifungal activity, via as-yet unknown mechanisms.

Keywords : antifungal activity, biocontrol, pyrroloquinoline quinine, solubilization of phosphate

Several biocontrol rhizobacteria have been utilized as microbial pesticides for the control of plant pathogens (Bloemberg and Lugtenberg, 2001). Antimicrobial products from beneficial bacteria include exoenzymes, including proteases, lipases, chitinases, and giucanases (Buchenauer, 1998; Dunlap et al., 1998; Park et al., 2005) and metabolites,

\footnotetext{
*Corresponding author.

Phone) +82-62-530-207i, FAX) +82-62-530-2079

E-mail)yckimyc@chonnam.ac.kr
}

including hydrogen cyanide (HCN) (Voisard et al., 1989), siderophores (Leong, 1986), antimicrobial compounds (Haas and Keel, 2003), and biosurfactants (Stanghellini and Miller, 1997). Competitive root colonization is another trait relevant to biocontrol (Chia-A-Woeng et al., 2000; Lugtenberg et al., 2001). Certain rhizobacteria have been also shown to augment plant growth via a variety of mechanisms, including the generation of indole-3-acetic acid (Lambrecht et al., 2000) and the solubilization of insoluble nutrients, such as phosphates, in soil (Goldstein, 1995), and to enhance plant growth and induce systemic resistance by production of butanediol (Han et al., 2006; Ryu et al., 2004).

Phosphorus is one of the most important macro-nutrients with regard to plant growth and development. However, phosphorus available in soil is readily converted into insoluble complexes, including tri-calcium-phosphate (Altomare et al., 1999). Insoluble phosphate can be solubilized by the organic acids generated by rhizobacteria. The conversion of glucose to gluconic acid by glucose dehydrogenases (GDH) is involved in this process, as is its oxidation to 2-ketogluconic acid via the activity of gluconate dehydrogenase (Goldstein, 1995). Glucose dehydrogenase requires pyrroloquinoline quinone $(\mathrm{PQQ})$ as a redox cofactor (Meulenberg et al., 1992). Genes encoding for the enzymes inherent to PQQ biosynthesis were cloned from Klebsiella pneumoniae and consisted of six open reading frames ( $p q q A$ to $p q q F$ ) (Meulenberg et al., 1992). The Dgluconic acid generated by the rhizobacterium Pseudomonas strain, AN5, was shown to inhibit the growth of Gaeumannomyces graminis var. tritici. However, the genes involved in the production of D-gluconic acid and the mechanisms of D-gluconic acid in antifungal activity have yet to be thoroughly characterized (Kaur et al., 2006). In addition, there have been no studies conducted, in our knowledge, regarding the functions of $p q q$ genes in antifungal activity.

Previously, we isolated a rhizobacterium, Serratia marcescens W1, which evidenced profound antifungal activities against a variety of plant pathogenic fungi, and 
also produced extracellular hydrolytic enzymes including chitinase and protease (Kim, 1996). In this paper, we address studies targeted toward the identification of the genes involved in the antifungal activity of this strain. We identified genes encoding for $S$. marcescens W1 chitinase and protease, as well as antifungal activity, via expression in $E$. coli. Neither chitinase nor protease was associated with antifungal activity. The expression of the $S$. marcescens $p q q$ biosynthetic genes in $E$. coli evidenced substantial antifungal effects.

\section{Materials and Methods}

Bacterial strains, plasmid and culture conditions. Bacteria were stored in $15 \%$ glycerol at $-70^{\circ} \mathrm{C}$. The rhizobacterium, S. marcescens $\mathrm{Wl}$, was isolated from cucumber fields in Suwon, Korea (Kim, 1996). The fungal pathogens, Magnaporthe grisea strain K101 and Cercospora citrullina were acquired from the NAIB collection (Suwon, South Korea). The fungal isolates were grown on potato dextrose agar (PDA, Difco Inc. Deteroit, MI) at $26^{\circ} \mathrm{C}$, and E. coli and $S$. marcescens W1 were grown on Luria Bertani (LB, Difco Inc., Deteroit, MI) agar medium, or in $\mathrm{LB}$ broth at $37^{\circ} \mathrm{C}$ and $30^{\circ} \mathrm{C}$, respectively. Antibiotics, when employed, were added at the following concentrations: $100 \mu \mathrm{g} / \mathrm{ml}$ of ampicillin for the growth of $E$. coli clones. Hydroxyapatite agar or broth medium (HY) containing glucose $10 \mathrm{~g}$, $\mathrm{MgSO}_{4} 0.2 \mathrm{~g}, \mathrm{NaCl} 1 \mathrm{~g}, \mathrm{CaCl}_{2} \cdot 2 \mathrm{H}_{2} \mathrm{O} 0.2 \mathrm{~g}, \mathrm{NH}_{4} \mathrm{NO}_{3} 1.5 \mathrm{~g}$, yeast extract $0.5 \mathrm{~g}$, and hydroxyapatite $4 \mathrm{~g}$ per liter of distilled water was employed to characterize the solubilization of the insoluble phosphate (Kim et al., 2002).

Construction of a genomic library and screening for biocontrol traits. A genomic library of $S$. marcescens W1 was constructed into a BamHI/XbaI digested Supercos vector (Stratagene cat. \#251301, La Jolla, CA, USA), using the partially Sau3AI-digested genomic DNA of S. marcescens $\mathrm{W} 1$, in accordance with the protocols established by Stratagene (La Jolla, CA, USA). The detection of antifungal genes in the cosmid was conducted via the screening of 3,000 clones for activity against $M$. grisea K101 or $C$. citrullina. The fungus was grown via the transfer of agar plugs into the centers of PDA agar plates, and fungal growth was facilitated by 5 days of incubation at room temperature, until the fungal mycelium covered $30 \%$ of the plate. Ten $\mu 1$ of $14 \mathrm{~h} \mathrm{LB}$ broth cultures of $E$. coli carrying cosmid clones $\left(10^{9} \mathrm{cfu} / \mathrm{ml}\right)$ were applied to the fungal mycelia, and the cultures were incubated for an additional 3 days. E. coli clones generating growth inhibition zones were retained for the purposes of characterization.

In order to isolate the chitinase or protease-producing cosmid clones, 3,000 E. coli transformants were inoculated onto M9 minimal medium agar containing $2 \%$ colloidal chitin (Yamura and John, 1961), or LB agar containing 1\% skim milk (Dahler et al., 1990). After 2 days of incubation, the E. coli strains evidencing clear zones around the inocula were selected for characterization.

DNA manipulation. Cloning and subcloning were con-ducted as previously described by Ausubel et al. (1989) and Sambrook and Russel (2001). The DNA fragments were isolated and purified from the agarose gels using a Zymoclean gel DNA recovery kit (Zymo Research, Orange, CA). Southern or colony hybridization was conducted using the nonradioactive Genius system (Roche Biochemicals, Indianapolis, IN). The plasmids were isolated with a miniplasmid purification system (Bioneer Inc., Daejeon, Republic of Korea). The chromosomal DNA was prepared via the hexadecyltrimethylammonium bromide (CTAB) method (Ausubel et al., 1989). Nucleotide sequence analyses were acquired using an ABI1301 DNA sequencer (Applied Biosystems, Foster City, CA) at the Korea Basic Science Institute (KBSI), Gwangju Branch. The nucleotide and deduced amino acid sequences were determined with NCBI Blast (http://www.ncbi.nlm.nih.gov) and Expasy (http:// www.expaxy.hcuge.ch/) software.

Expression of $S$. marcescens W1 $p q q$ genes in $E$. coli. Plasmids harboring various subclones of $S$. marcescens W1 $p q q$ genes were transformed into E. coli $\mathrm{DH} 5 \alpha$. The transformants were grown for 24 hours in HY broth with agitation at $200 \mathrm{rpm}$ at $30^{\circ} \mathrm{C}$ from an inoculum of $10^{6} \mathrm{cfu} /$ $100 \mathrm{ml}$ medium. The $\mathrm{pH}$ of the culture filtrate was then measured with a pH meter, and the organic acids production were determined via HPLC analysis, as previously described (Kim et al., 2002). The soluble phosphorus concentrations of the culture filtrates were determined using a spectrophotometer at $660 \mathrm{~nm}$ (Kim et al., 2002).

GenBank accession number. The nucleotide and amino acid sequences of the $S$. marcescens W1 extracellular chitinase and $p q q$ genes were deposited into the GenBank database under the accession numbers DQ868535 and DQ868536, respectively.

\section{Result and Discussion}

Cloning of chitinase and protease genes from $S$. marcescens W1. The screening of 3,000 E. coli cosmid clones with genomic DNA fragments from $S$. marcescens W1 revealed seven clones that generated extracellular chitinase, and five clones that generated extracellular protease. The subcloning of one $(\mathrm{C} 1)$ of the cosmid clones 
Table 1. Fungal, bacterial strains and plasmids used in this study

\begin{tabular}{|c|c|c|}
\hline Organism, strain or plasmid & Relevant genotype or description & Source or reference \\
\hline \multicolumn{3}{|l|}{ Fungal strains } \\
\hline Magnaporthe grisea & Rice blast & NASTI collection ${ }^{\mathrm{a}}$ \\
\hline Cercospora citrullina & Cucumber leaf spot & NASTI collection \\
\hline \multicolumn{3}{|l|}{ Bacterial strains } \\
\hline \multicolumn{3}{|l|}{ Serratia marcescens } \\
\hline W1 & Antagonist to plant-fungal pathogen & Isolated from soil \\
\hline \multicolumn{3}{|l|}{ Escherichia coli } \\
\hline TG1 & 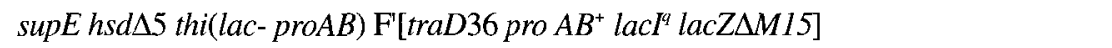 & NASTI collection \\
\hline NM554 & $\begin{array}{l}\text { recAl3,araD139, } \Delta \text { (ara,leu) 7696, } \Delta \text { (lac) 17A,galU,galK, } \\
\text { hsrR,rpsl(str'),mcrA,merB }\end{array}$ & Stratagene \\
\hline $\mathrm{AG1}$ & recA1,endA1,gyrA96,thi-1, hsdR17( $\left.r_{K^{-}}, m_{K}+\right)$, supE44,relAl & Stratagene \\
\hline $\mathrm{DH} 5 \alpha$ & $\begin{array}{l}\text { supE44 } \triangle \text { lac } U 169(\varphi 80 \text { lacZD M15) hsdR17 recAl endAl } \\
\text { gyrA9 thi-1 relAl }\end{array}$ & Stratagene \\
\hline \multicolumn{3}{|l|}{ Plasmids } \\
\hline SuperCos & Cosmid Vector, Amp ${ }^{r}$ Stratagene & \\
\hline pUC18 & Cloning vector, $\mathrm{Amp}^{\mathrm{r}}$ & Promega \\
\hline pUC19 & Cloning vector, Amp ${ }^{r}$ & Promega \\
\hline pSUPC1 & $35 \mathrm{~kb}$ fragment in SuperCos, chitinase $(+)$ & This study $(\mathrm{Cl})$ \\
\hline pCHI-I & $11 \mathrm{~kb}$ EcoRI fragment from $\mathrm{pSUPCl}$ cloned in pUC19, chitinase $(+)$ & This study(C38) \\
\hline pCHI-II & $2.4 \mathrm{~kb} E c o \mathrm{RI} / K p n \mathrm{I}$ fragment from $\mathrm{pCHI}-\mathrm{I}$ cloned in pUC18, chitinase(+) & This study(C94) \\
\hline pSUPC6 & $35 \mathrm{~kb}$ fragment in SuperCos, protease $(+)$ & This study(C6) \\
\hline pPRO-I & $4.7 \mathrm{~kb} E c o \mathrm{RI}$ fragment from pSUPC6 cloned in pUC19, protease $(+)$ & This study(C27) \\
\hline pPRO-II & $3 \mathrm{~kb}$ HincII fragment from pPRO-I cloned in pUC19, protease(+) & This study(C46) \\
\hline pSUPC5 & $35 \mathrm{~kb}$ fragment in SuperCos, antifungal activity(+) & This study(C5) \\
\hline pSUPC 32 & $27 \mathrm{~kb}$ fragment in SuperCos, antifungal activity $(+)$ & This study(C32) \\
\hline pANT-I & $8.2 \mathrm{~kb}$ HindIII fragment from pSUPC32 cloned in pUC19, antifungal activity $(+)$ & This study(C52) \\
\hline pANT-II & $6.9 \mathrm{~kb}$ HindIII/EcoRI fragment from pANT-I cloned in pUC19, antifungal activity $(+)$ & This study(C78) \\
\hline pANT-III & $6.9 \mathrm{~kb}$ HindIII/EcoRI fragment from pANT-I cloned in pUC18, antifungal activity $(+)$ & This study(C81) \\
\hline pANT-IV & $4.6 \mathrm{~kb}$ SalI/HindIII fragment from pANT-I cloned in pUC18, antifungal activity(-) & This study(C74) \\
\hline pANT-VI & $3.6 \mathrm{~kb} H$ ind III $/ S a l \mathrm{I}$ fragment from pANT-I cloned in pUC19, antifungal activity(-) & This study(C76) \\
\hline pPRO-III & $1.3 \mathrm{~kb}$ EcoRI/HindIII fragment from pANT-I cloned in pUC18, antifungal activity(-) & This study(C79) \\
\hline
\end{tabular}

"National Agricultural Science and Technology Institute

into pUC19, C94 (pCHI-II), generated a $2.4 \mathrm{~kb}$ EcoR1/ KpnI fragment which encoded for chitinase activity. The chitinase gene (chiB) of $S$. marcescens W1 harbored a predicted 1,693 bp ORF with deduced amino acids of 487 residues, corresponding to a subunit molecular weight of approximately $55.6 \mathrm{kD}$ and $\mathrm{pI}$ 6.26. The deduced amino acid sequence of $S$. marcescens Wl chiB gene evidenced the conserved catalytic site, YGFDGVDIDIWEYP, and exhibited an identity of $92 \%$ with the deduced amino acid sequence of the chiB gene of $S$. marcescens QMB1466, but evidenced no homology with the chiA gene of this strain. A putative signal peptide was detected in the deduced amino acid sequence of the chiB gene of $S$. marcescens W1 (Watanabe et al., 1997).

Another cosmid, clone pSUPC6, which conditioned the highest levels of protease activity, was subcloned to generate C46 (pPRO-II) harboring a $3.0 \mathrm{~kb}$ HincII fragment that encoded for protease activity (Table 1). The protease gene in this fragment had a predicted 1,044 bp open reading frame, and a deduced amino acid of 347 residues, corresponding to a subunit molecular weight of approximately $38.7 \mathrm{kD}$ and $\mathrm{pI} 12.16$. The $S$. marcescens $\mathrm{W} 1$ protease gene evidenced an identity of $73.4 \%$ with the deduced amino acid sequence of the protease gene of $S$. marcescens ATCC21074, and $53.5 \%$ with that of Erwinia carotovora. The putative zinc binding sites, HELTHG and QSGALNESLSDVFGS, were located downstream of the start codon (data not shown).

Neither the chitinase nor protease subclones (C94 and C46) evidenced antifungal activity against $M$. grisea (data not shown). Chitin and protein are primary cell wall components of plant pathogenic fungi. Therefore, chitinase 
and protease production are believed to be involved in the biological control of phytopathogenic fungi by biocontrol microorganisms, including bacteria and fungi (Buchenauer, 1998; Dunlap et al., 1998; Park et al., 2005). In addition, the metalloprotease of $S$. marcescens has been demonstrated to be involved in pathogenicity in insects (Flyg and Xanthopoulos, 1983). However, our results indicated that the expression of chitinase or protease from $S$. marcescens W1 in E. coli did not inhibit the growth of $M$. grisea and $C$. citrullina. We have no direct evidence which might explain this observation, but we theorize that the overexpression of single chitinase or protease in $E$. coli may be insufficient with regard to the inhibition of fungal pathogenic growth. Investigations are currently underway to determine the roles of chitinase or protease in antifungal activity against plant pathogenic fungi, via the generation of single or double knockout mutants of the extracellular enzymes.

Cloning of antifungal genes of $S$. marcescens W1. The screening of the 3,000 cosmid library clones for growth inhibitory effects against $M$. grisea K101 demonstrated activity from cosmid clones C5 (35 kb) and C32 (27 kb), which evidenced some common restriction fragments (Fig. 1). A $1.3 \mathrm{~kb}$ EcoRI/HindIII fragment, when employed as a probe, detected an $8.2 \mathrm{~kb}$ HindIII fragment from C32 and a $6.9 \mathrm{~kb} H i n \mathrm{dIII} / E c o \mathrm{RI}$ fragment from C32. The sequencing of the $8.2 \mathrm{~kb}$ fragment evidenced seven putative ORFs, six of which evidenced similarity to other $p p q$ genes (Kim et al., 2003; Meulengerg et al., 1992). A putative ORF exhibiting homology with a membrane dipeptidase was also located upstream of the proposed $p q q A$ gene. Similar dipeptidases are zinc-dependent metalloenzymes, which hydrolyze a wide variety of dipeptides (Adachi and Tsujimoto, 1995). Our BLAST search analysis of the dipeptidase gene showed that the dipeptidase homologues were conserved upstream of the $p q q$ operons of Acinetobacter calcoaceticus and $K$. pneumoniae.

The putative 77-bp gene, pqqA, encoded a 25-amino acid peptide, with a subunit size of $2.98 \mathrm{kD}$ and a $\mathrm{pI}$ of 5.94. The presence of glutamic acid and tyrosine residues at positions 8,17 , and 21 was consistent with other deduced PQQA proteins. A frame shift in $K$. pmeumoniae pqqA resulted in an abrogation of PQQ biosynthesis (Meulenberg et al., 1992). In another study, it was demonstrated that conserved glutamic acid and tyrosine in PQQA are the principal precursors for PQQ biosynthesis (Goosen et al., 1992). Consequently, the primary function of the PQQA is to generate PQQ biosynthesis precursors.

The 855-bp pqqB encodes a 284-amino acid peptide, with subunits of approximately $30.5 \mathrm{kD}$ and $\mathrm{pI} 9.39$. Although PQQB did not harbor hydrophobic stretches, mutant analysis in $K$. pneumoniae indicated that PQQB may be involved in the transport of PQQ across the cytoplasmic membrane into the periplasm, via the modification of an existing transport system (Velterop et al., 1995). The 749-bp pqqC encoded a predicted 249 amino acids, with subunits of $28.76 \mathrm{kD}$ and $\mathrm{pI} 6.45$. The PQQC protein in $K$. pneumoniae has been hypothesized to catalyze the last step in PQQ biosynthesis (Velterop et al., 1995). The 278-bp $p q q D$ encoded a predicted peptide of 92 amino acids, with an approximately $10.49 \mathrm{kD}$ and a $\mathrm{pI}$ of 5.84 . The 1,112-bp $p q q E$ encoded a peptide of 370 amino acids, with an approximately $41.49 \mathrm{kD}$ and a $\mathrm{pI}$ of 6.31 . The 1,841-bp $p q q F$ gene encoded a predicted $66.7 \mathrm{kD}, 614$ amino acid peptide, with a pI of 10.66. The deduced amino acid sequences of the pqqF genes from $S$. marcescens W1 evidenced a high degree of similarity to $E$. coli protease III and other proteases (Meulenberg et al., 1992). The roles in PQQ biosynthesis played by the proteins encoded by $p q q D$,

A.

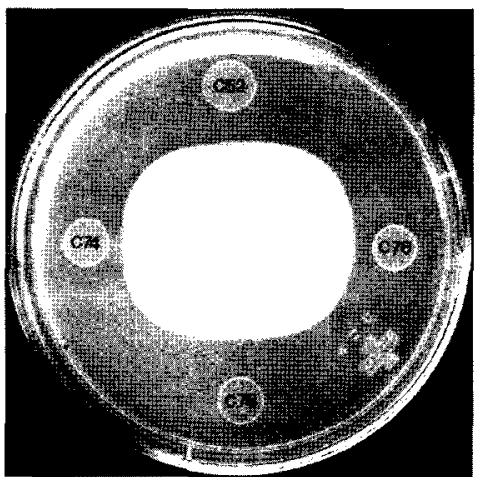

B.

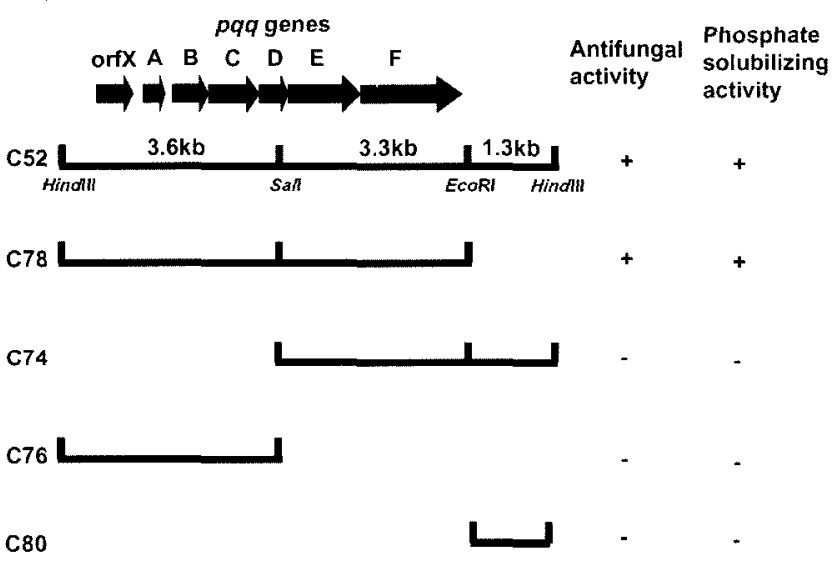

Fig. 1. Antifungal activities, solubilizing phosphate, and restriction map of the sequence in the transformants with the full sequence of $p p q$ genes (C52) and its restricted fragments. A: Antifungal activity of constructs with complete $p q q$ genes, $8.2 \mathrm{~kb}$ $\mathrm{C} 52$ and $6.9 \mathrm{~kb} \mathrm{C78}$, and deleted genes. B: Restriction map of subclones obtained from $8.2 \mathrm{~kb}$ C52 and antifungal activities against $M$. grisea and the phosphate-solubilizing activities of the subclones. 
Table 2. Changes in $\mathrm{pH}$, gluconic acid production, and soluble phosphate concentration of culture filtrate of $E$. coli DH5 $\alpha$ containing $p q q$ genes $^{a}$

\begin{tabular}{lccc}
\hline \hline Bacterial isolate & $\mathrm{pH}$ & $\begin{array}{c}\text { Gluconic acid } \\
(\mu \mathrm{g} / \mathrm{ml})\end{array}$ & $\begin{array}{c}\text { Soluble phosphate } \\
(\mu \mathrm{g} / \mathrm{ml})\end{array}$ \\
\hline E. coli $\mathrm{DH} 5 \alpha$ & $4.99^{\mathrm{b}}$ & $5,239^{\mathrm{b}}$ & $213^{\mathrm{b}}$ \\
S. marcescens $\mathrm{W} 1$ & 4.25 & 65,469 & 1,102 \\
E. coli $\mathrm{C} 52$ & 4.53 & 112,227 & 921 \\
E. coli $\mathrm{C} 78$ & 4.13 & 107,247 & 954 \\
\hline
\end{tabular}

${ }^{a}$ Cells were grown in culture medium containing $0.4 \%$ hydroxyapatite at $30^{\circ} \mathrm{C}$ for 24 hours. Culture filtrates were assayed for $\mathrm{pH}$, gluconic acid concentration, and soluble phosphate as described in Materials and methods.

${ }^{\mathrm{b}}$ Values are means of three independent experiments.

$p q q E$, and $p q q F$ remain to be further elucidated.

Expression of $S$. marcescens $W 1$ pqq genes in $E$. coli. The $6.9 \mathrm{~kb} H i n \mathrm{dIII} / E c o$ RI subclone in pUC19 harbored the full set of $p q q$ genes from $S$. marcescens $\mathrm{W} 1$ that conditioned antifungal activity, whereas the smaller subclones, the 4.6 $\mathrm{kb}$ SalJ/HindIII fragment, $3.6 \mathrm{~kb}$ HindIII/Sall fragment, and the $1.3 \mathrm{~kb}$ EcoRI/HindIII fragment, lacked this property and also lacked the full complement of $p q q$ genes (Fig. 1).

When $E$. coli DH5 $\alpha$ harbored the vector plasmid with the full set of $S$. marcescens $\mathrm{W} 1 \mathrm{pqq}$ genes, the solubilization of phosphate was observed, whereas the smaller subclones, harboring incomplete $p p q$ genes, did not exhibit such activity (Table 2 and Fig. 1). In arother study, phosphatesolubilizing ability was correlated with acidification mediated by the generation of gluconic acid (Van Schie et al., 1987). Therefore, we evaluated the changes in $\mathrm{pH}$ occurring when $E$. coli constructs harboring different subclones of the $S$. marcescens $p q q$ genes were grown in liquid medium containing hydroxyapatite. E. coli $\mathrm{DH} 5 \alpha$ cultures harboring the vector with the partial $p q q$ genes remained at pH 5.5 for up to 48 hours of growth (Table 2), whereas those with the full set of $p q q$ genes acidified the culture filtrate to $\mathrm{pH} 4.0$ within 24 hours (Table 2).

We determined (Table 2) that reductions in $\mathrm{pH}$ value corresponded to higher levels of gluconic acid generation. Reductions in $\mathrm{pH}$ corresponded with an increase in the levels of soluble phosphate in the culture medium; soluble phosphate levels remained at $950 \mathrm{ppm}$ for the strain expressing the complete complement of the $p p q$ genes, compared with less than $210 \mathrm{ppm}$ for the strain harboring only the vector with the partial pqq genes (Fig. 4).

In summary, we have demonstrated in this study that the genetic manipulation of $E$. coli to express $p q q$ genes endows the strains with an antifungal activity against $M$. grisea and $C$. citrullina. We speculate that the $p p q$ genes increased the generation of gluconic acid, thereby resulting in a drop in $\mathrm{pH}$ values that may prove stressful, thereby inhibiting the growth of the tested fungal pathogens. Another possibility is that PQQ generation in E. coli functioned as a cofactor for the production of novel antimicrobial compounds. We are currently investigating this possibility, via the fractionation of antifungal compounds from culture filtrates of $p q q$ gene-expressing $E$. coli. The results of our recent study showed that $p q q$ mutants of Enterobacter intermedium lost their phosphate solubilizing activity and antifungal activity against $M$. grisea (unpublished data). How the function of the $p p q$ gene in the rhizospherecompetent Serratia isolate affects antifungal activity awaits clarification.

\section{Acknowledgment}

This work was supported by a grant from the Technology Development Program for Agriculture and Forestry, Ministry of Agriculture and Forestry, Republic of Korea.

\section{References}

Adachi, H. and Tsujimoto, M. 1995. Cloning and expression of dipeptidase from Acinetobacter calcoaceticus ATCC23055. J. Biochem. 118:555-561.

Altomare, C., Norvell, W. A., Bjorkman, T. and Harman, G. E. 1999. Solubilization of phosphates and micronutrients by the plant growth promoting and biocontrol fungus Trichoderma harzianum Fifai 1295-22. Appl. Environ. Microbiol. 65:29262933.

Ausubel, F. M., Brent, R., Kingston, R. E., Moore, D. D., Seidman, J. G., Smith, J. A. and Struhl, K. 1989. Current protocols in molecular biology. New York: John Wiley and Sons.

Bloemberg, B. G. and Lugtenberg, B. J. J. 2001. Molecular basis of plant growth promotion and biocontrol by rhizobacteria. Curr. Opin. Plant Biol. 4:343-350.

Buchenauer, H. 1998. Biological control of soil-borne diseases by rhizobacteria. Z. Pflanzenkrankh Pflanzenschutz 105:329-348.

Chin-A-Woeng, T. F. C., Bloemberg, G. V., Mulders, I. H. M., Dekkers, L. C. and Lugtenberg, B. J. J. 2000. Root colonization by phenazine-1-carboxamide-producing bacterium Pseudomonas chlororaphis PCL1391 is essential for biocontrol of tomato foot and root rot. Mol. Plant-Microbe Interact. 13:1340-1345.

Dahler, G S., Barras, F. and Keen, N. T. 1990. Cloning of genes encoding extracellular metalloproteases from Erwinia chrysanthemi EC16. J. Bacteriol. 172:5803-5815.

Dunlap, C., Moënne-Loccoz, Y., McCarthy, J., Higgins, P., Powell, J., Dowling, D. N. and O'Gara, F. 1998. Combining proteolytic and phloroglucinol producing bacteria for improved biocontrol of Pythium mediated damping off of sugar beet. Plant Pathol. 47:299-307.

Flyg, C. and Xanthopoulos, K. G. 1983. Insect pathogenic properties of Serratia marcescens. Passive and active resistance to insect immunity studied with protease-deficient and phage- 
resistant mutants. J. Gen. Microbiol. 129:453-464.

Goosen, N., Huinen, R. G. M. and Putte, P. 1992. A 24-aminoacid polypeptide is essential for the biosynthesis of the coenzyme pyrroloquinoline quinone. J. Bacteriol. 174:1426-1427.

Goldstein, A. 1995. Recent progress in understanding the molecular genetics and biochemistry of calcium phosphate solubilization by gram negative bacteria. Biol. Agric. Hortic. 12:185193.

Haas, D. and Keel, C. 2003. Regulation of antibiotic production in root-colonizing Pseudomonas spp. and relevance for biological control of plant disease. Annu. Rev. Phytopathol. 41:117153.

Han, S. H., Lee, S. J., Moon, J. H., Yang, K. Y., Cho, B. H., Kim, K. Y., Kim, Y. W., Lee, M. C., Anderson, A. J. and Kim, Y. C. 2006. GacS-dependent production of 2R, 3R-butanediol by Pseudomonas chlororaphis $\mathrm{O6}$ is a major determinant for eliciting systemic resistance against Erwinia carotovora but not against Pseudomonas syringae pv. tabaci in tobacco. Mol. Plant-Microbe Interact. 19:924-930.

Kaur, R., Macleod, J., Foley, W. and Nayudu, M. 2006. Gluconic acid: An antifungal agent produced by Pseudomonas species in biological control of take all. Phytochemistry 67:595-604.

Kim, C. H., Han, S. H., Kim, K. Y., Cho, B. H., Kim, Y. H., Koo, B. S. and Kim, Y. C. 2003. Cloning and expression of pyrroloquinoline quinone (PQQ) genes from a phosphate-solubilizing bacterium Enterobacter intermedium. Curr. Microbiol. 47: 457-461.

Kim, K. Y., Hwang, B, H., Kim, Y. W., Kim, H. J., Park, K. H., Kim, Y. C. and Seong, K. Y. 2002. Organic acid production and phosphate solubilization by Enterobacter intermedium 60 2G. Korean J. Soil Sci. Fert. 35:59-67.

Kim, Y. H. 1996. Isolation and characterization of antipathogenic genes of antagonistic bacterium, Serratia marcescens W1 to rice blast pathogen. $\mathrm{Ph}$. $\mathrm{D}$ thesis. Chonnam National University.

Lambrecht, M., Okon, Y., Vande Broek, A. and Vanderleyden, J. 2000. Indole-3-acetic acid: A reciprocal signaling molecule in bacteria-plant interactions. Trends Microbiol. 8:298-300.

Leong, J. 1986. Siderophores: Their biochemistry and possible role in the biocontrol of plant pathogens. Annu. Rev. Phyto- pathol. 24:187-209.

Lugtenberg, B. J. J., Dekkers, L. C. and Bloemberg, G. V. 2001. Molecular determinants of rhizosphere colonization by Pseudomonas. Annu. Rev. Phytopathol. 39:461-490.

Meulenberg, J. J. M., Sellink, E., Riegman, N. H. and Postma, P. W. 1992. Nucleotide sequence and structure of the Klebsiella pneumoniae pqq operon. Mol. Gen. Genet. 232:284-294.

Park, S. K., Lee, M-C. and Harman, G. E. 2005. The biocontrol activity of Chromobacterium sp. strain C-61 against Rhizoctonia solani depends on the productive ability of chitinase. Plant Pathol. J. 21:275-282.

Ryu, C. M., Farag, M. A., Hu, C. H., Reddy, M. S., Kloepper, J. W. and Pare, P. W. 2004. Bacterial volatiles induce systemic resistance in Arabidopsis. Plant Physiol. 134:1017-1026.

Sambrook, J. and Russell, D. W. 2001. Molecular cloning: a laboratory manual, 3rd ed. Cold Spring Harbor Laboratory Press, Cold Spring Harbor, N.Y.

Stanghellini, M. E. and Miller, R. M. 1997. Biosurfactants. Their identity and potential efficacy in the biological control of zoosporic plant pathogens. Plant Dis. 81:4-12.

Van Schie, B. J., De Mooy, O. H., Linton, J. D., Van Dijken, J. P. and Kuenen, J. G. 1987. PQQ-dependent production of gluconic acid by Acinetobacter, Agrobacterium, and Rhizobium species. J. Gen. Microbiol. 133:867-875.

Velterop, J. S., Sellink, E., Meulenberg, J. M., David, S., Bulder, I. and Postma, P. W. 1995. Synthesis of pyrroloquinolin quinone in vivo and in vitro and detection of an intermediate in the biosynthetic pathway. J. Bacteriol. 177:5088-5098.

Voisard, C., Keel, C., Haas, D. and Defago, G. 1989. Cyanide production by Pseudomonas fluorescens helps suppress black root rot of tobacco under gnotobiotic conditions. EMBO J. 8:351-358.

Yamura, L. and John, L. L. 1961. Chitin media for selective isolation and culture of Actinomycetes. Phytopathology 52:318323.

Watanabe, T., Kimura, K., Sumiya, T., Nikidou, N., Suzuki, K., Suzuki, M., Taiyoji, M., Ferrer, S. and Reque, M. 1997. Genetic analysis of the chitinase system of Serratia marcescens 2170. J. Bacteriol. 179:7111-7117. 